\title{
KNOWLEDGE RESOURCES FOR UNIVERSITY SPINOFFS: THE ROLE OF THE ACADEMIC ENTREPRENEUR
}

\author{
MARCUS W. Y. HO \\ Auckland University of Technology \\ Auckland, New Zealand \\ MARIE G. WILSON \\ The University of Auckland Business School
}

\section{INTRODUCTION}

The commercialization of scientific and technological knowledge from universities is believed to foster economic growth, innovation, and wealth creation (Lockett \& Wright, 2005b). The specific processes by which academic entrepreneurs build organizations and how institutional linkages impact the emergence of such knowledge-based spin-offs is, however, largely unexplored (Hindle \& Yencken, 2004; Lockett et al., 2005a). A key developmental process for spinoffs is the transfer of the tacit knowledge of inventors across to new ventures (Legge \& Hindle, 1997; Thorburn, 2000). Hindle and Yencken (2004) present a theoretical framework for understanding how the knowledge and expertise of the entrepreneur is transferred through research commercialization. Their model incorporates entrepreneurial inputs (such as tacit knowledge), the external environment (such as competition), and the resource inputs from investors and other interests.

The literature on academic entrepreneurs argues that the idiosyncratic nature of entrepreneurial opportunity recognition and the capabilities required to transform opportunities to commercialized activities are central to spinoffs. In other words, the 'capability effect' (Colombo \& Grilli, 2005) of scientist-entrepreneurs offer unique and inimitable capabilities that can be used sustain competitive advantage of other firms (Leonard, 1992). In investigating the role of academic entrepreneurs in the building of their firms, the majority of studies have often centered on the human capital or social capital of their founders (Murray, 2004; Zucker, Darby, $\&$ Brewer, 1998). While it may seem obvious that academic founders contribute in some way to the spinoff, the links with the parent institution are hugely influential, particularly on the resource endowments of the spinoff (DiGregorio \& Shane, 2003; Moray \& Clarysse, 2005). However, the literature on academic entrepreneurs has not captured the dynamic links between the parent institutions and the spinoffs. By integrating the entrepreneurship literature on founders with the spinoff literature with reference to knowledge and resource endowments, it is hoped that this study presents a more dynamic link between the influence of the insitutional and external environments with the organization building activities of founders.

\section{RESEARCH DESIGN}

The analysis presented below is based on an exploratory multiple-case study design on a sample of three human pharmaceutical biotechnology spinoffs from a prominent New Zealand university. The cases for this research were selected on the following criteria: spinoffs were aged ten years or less to qualify as a new venture or start-up; were founded by an academic to exploit their own technology; and an identifiable founder was still associated with the company 
(as a key informant). This criteria is consistent with studies of emerging high technology firms (Baron et al., 1996; Burton, 1995; Finegold \& Frenkel, 2006). The focus on a single biotechnology niche, human therapeutics, and a single region were designed to reduce environmental variance. The research design is focused at the individual, organizational and institutional level of analysis, using a mixed methods approach (Yin, 1994). For the purposes of this study, interviews (with the academic entrepreneurs, senior managers and staff), observation, participant observation, written documents, archival data (publicly available company reports and media reports including reports from TTO of the university), and observations were used to construct complex case studies - which are presented here in abridged format. Representative quotes from the informants are presented in italics.

\section{FINDINGS}

The three cases, AlphaTech, BetaTech and GammaTech represent three spinoff companies with varying linkages to their institutional origins. Each case highlights the interaction between the insitutional linkages, knowledge endowment and founder organization building (as summarized in Table 1).

Table One About Here

\section{Case One: AlphaTech}

AlphaTech biotechnology was founded in 1994 and has grown to over 150 employees from an initial start-up of 25. AlphaTech has one founder, Alpha, a full-time professor at the university prior to founding AlphaTech. He has a background in commercial science, including commercial biotechnology companies, though not as a founder. AlphaTech began when Alpha returned from sabbatical as a science director in a commercial biotechnology company and "began to realize that the balance of power was shifting and the best science is actually being done in these new creative young companies". Six months after development of a business plan, AlphaTech was spun-off. AlphaTech is distinguished by immediate and full separation from its institutional origins. From its inception, Alpha resigned from his position at the university and located the firm away from the university environment. This was facilitated by private equity funding from key stakeholders and public research funding that was transferred from the university to the company. AlphaTech achieved initial public offering (IPO) in 2000.

In the initial stages of spin-off for AlphaTech, much of the organization building of the founder was focused on networking (with lawyers, venture capitalists and university stakeholders) for start-up funding. Having little experience in founding a company, Alpha relied on key advisors, who influenced the emergent structure. Aside from these influences, Alpha was reliant on his own professional socialization and prior work experiences in establishing the business plan, and placed himself outside the University for legitimacy.

...to the investment community... I was an individual trying to raise money and I had a professorship in the university... a very secure position ... they are always 
reluctant to put money into an individual who's got another job... I think that when I left and decided this was it... they had more confidence to invest...

Alpha realized that he needed the employees in his laboratory to make the company work. He approached the university to allow the transfer of research funds from the university to the new company along with its people. This would represent a key insitutional influence on AlphaTech and an important milestone in the formation of the spinoff. AlphaTech was able to launch as a viable independent separate spinoff from its insitutional origins because it was able to obtain funding and transfer a core knowledge resource - a working discovery team.

\section{Case Two: BetaTech}

Beta Tech has two founders, Beta1 and Beta2. Beta1 comes from a commercial background and was involved through the TTO (technology transfer office) of the university. BetaTech was the first company that Beta2, the academic founder, been involved with.

The company formed because I had IP which I wanted to develop... I had persuaded the university that it was well placed to circumscribe this IP in a separate ... and then ...one angel investor appeared who was prepared to help support the origin of the company...

With an interested investor, Beta2 sought help from the university, who introduced Beta2 to Founder Beta1, through the TTO. Both pursued seed funding of the company. While BetaTech was founded in 1994, it was not until the year 2000 that the company was privatized. BetaTech was based within the university with particular attachment to the research institute that Beta2 had established. Beta2 remained a faculty member while developing the spinoff; Beta1 was responsible for fundraising and "running the business side of things". The initial human capital of BetaTech was assembled from the scientists that were working at Beta2's research institute. The firm grew from 15 staff (all from the Founder's lab), to 50 staff, all in the original research institute facility in the university precinct. Two years post-privatization, staff numbers were cut to reduce the cash "burn-rate" in the lead up to clinical trials, with some of the scientists leaving and most transferring back to the research institute.

From its beginnings, Beta 2 worked closely with Beta1 to establish a viable spinoff, firstly by transferring and negotiating the required IP and licensing policies into a separate entity from the university, and secondly by negotiating the required human capital requirements for commercializing the IP. The funding was achieved through the joint efforts of the two founders utilizing the university's networks, and private and institutional investors. With regard to the knowledge resources of BetaTech, senior managers and scientists within BetaTech were recruited through Beta2's networks or through prior working relationships at the university.

\section{Case Three: GammaTech}

GammaTech was founded in 1995 and employs 70 people. GammaTech maintains close institutional links by having its laboratories established within the university, while "ringfencing" IP and financial resources. GammaTech has one founder, Gamma, who remains a faculty member of the university. Founder Gamma has a history of successfully patenting his 
own discoveries and has had previous founding success in the industry. Gamma personally funded his own research, and GammaTech, from his prior successful biotechnology ventures. His entry terms when joining the University included commercialization options. Most of Gamma's IP has been vested in GammaTech which was privatized in 1999.

In the years before GammaTech was launched, Gamma garnered financial and operational resources through his personal and professional networks. Gamma believed in the potential benefits of commercializing the research and believed that the only way to move forward with the research was as a commercialized biotechnology company. Gamma had a specific business model "in mind" from his prior founding experience and assembled the founding team prior to launching GammaTech as a company. GammaTech is able to draw on resources from the university through its co-locational links by combining scientific expertise and laboratory resources, while still maintaining independence. The knowledge resources that GammaTech is able to draw on are very much dependent on Gamma and his close relationships with the university. GammaTech draws on the human capital resource of the university by actively recruiting new graduate students, visitors and other "university" resources. GammaTech represents a spinoff that has not "graduated" from its university origins yet functions as an independent entity. In this sense, GammaTech is able to enjoy the best of both worlds, as an independent company with deep resource links to its university origins.

\section{DISCUSSION}

The organization building activities of the founders described above allows us to analyze the formation of the spinoffs, including the influence of inter-institutional linkages and knowledge transfers. In seceding from its institutional origins, several important factors emerge, particularly for the resource endowments of AlphaTech. Firstly, the decision to have complete separation from its insitutional origins was a desire to obtain resources and legitimacy. This underscores the importance for having strong financial reserves to establish independence and mobilize resources (Finegold \& Frenkel, 2006). Secondly, AlphaTech began with a core group of employees from Alpha's laboratories, a knowledge resource that was essential in the building of AlphaTech. The severance from institutional origins required the hiring of outside expertise to establish human capital and ongoing knowledge resource flows for the company.

In contrast to AlphaTech, BetaTech maintained close linkages with its university origins. One of the founders of BetaTech, Beta2, was both the inventor-founder and research director of a university research center. This close link with the insitutional origins allowed human capital and knowledge resources to be managed and leveraged by the inventor-founder for BetaTech. Additional expertise around its commercialization activities was often buffered (through the research institute structure) or bought (outsourced). The ability to form a symbiotic relationship with the university was generally attributed to Beta2's relationship in the university. Interinstitutional links are thought to imbue spinoffs with access to resources or expertise from the host. For BetaTech, the links were an important factor for the transfer - and maintenance - of knowledge and human capital (Thorburn, 2000).

GammaTech's institutional links, while on the outside seemingly similar to BetaTech, were predicated on the relationship of Gamma to the university at entry. GammaTech also differed from BetaTech in that its insitutional links were unidirectional. GammaTech had established co-location with the university (and shared some resources including certain expertise and knowledge resources). Gamma was able to maintain independence while 
leveraging resource links - including access to key talent - because he was the resident commercial expert and an active member of the faculty. While GammaTech maintained a core cadre of knowledge resources through its established human capital (based on Gamma's laboratories), additional knowledge resources such as young research students, post-docs and scientists could be actively sought when required. While GammaTech faced much of the same environmental constraints as the prior cases (limited labor pools and competition), GammaTech could leverage the laboratory and mentoring model of universities to "build" rather than "buy" human capital. In this way, the spinoff was embedded within the insitutional origins and afforded resource protection. The inter-institutional links with the university allows resources to be found and utilized which enhanced GammaTech's viability in human capital terms.

\section{THEORETICAL IMPLICATIONS}

Examining how each company is linked to its institutional context offers some explanation for the heterogeneity of resources endowments and the organization building processes around those knowledge resources. In particular, the cases reveal that the extent of linkage between the spin-off companies and their university origins differentiates spinoff's abilities to capture the required resources for viability. The three cases demonstrate the extent of influence on the knowledge resources and the founders' organization building activities.

There is evidence to suggest that the mechanism through which university prior knowledge and success can be transferred to the spinoff is either through the use of inventorentrepreneurs (as demonstrated in AlphaTech and BetaTech), or through prior entrepreneurial success (as in GammaTech). Our research demonstrates the mechanisms through which entrepreneurial capital (Alvarez \& Busenitz, 2001; Hindle \& Frenkel, 2004) interacts with the institutional linkages and resource endowments of the spinoff firm (Moray \& Clarysse, 2005; Rothaermel et al., 2005). By establishing within their university origins, BetaTech and GammaTech leveraged the existing knowledge resources within the university and broader scientific communities, though this may have limited their financial resources and growth trajectories. The social networks of the founders of BetaTech and GammaTech were enhanced by their positions within the institutions, opening access to scarce knowledge resources (Burt, 2000; Lin, 2002; Scholten et al., 2001). On the other hand, AlphaTech separated itself from its institutional origins and relied on a traditional "business" model; an isomorphic approach which facilitated much greater access to financial backing than BetaTech or GammaTech. This suggests that inventor-entrepreneurs bring not only their considerable human capital, but also their social networks in the parent, to be exploited by the new firm (Davidsson \& Honig, 2003).

The impact of these institutional links on the form of the spinoff may then be mediated by each founder's understanding of the right ways to organize within their environments. BetaTech relied on external specialist contractors, and buffered and contracted resources with the colocated research institute. While BetaTech outsourced important expertise, GammaTech believed that the best way to leverage the knowledge resources was internal development. AlphaTech and its founder believed that the best way to establish knowledge and human capital resource was through the use of a formalized professional model and the international "marketplace". This research provides evidence that institutional links impact the emergence of the spinoff through an interaction with founders' organization building as well as directly through the networks and processes of the organization. This study extends the research suggestions that the initial competencies of the start up are similar to the competencies of the founder (Cooper \& Bruno, 
1977); founders in our study appear to adopt spinoff models that are akin to their own perspectives on knowledge management. Our research also suggests that prior research linking inventor-founder involvement with lower rates of firm failure (Rothaermel \& Thursby, 2005) may be explained through the inventor-founder's considerable resource links with the universities in which they are embedded. This gives support to the notion that firms accrue credibility (Mian, 1997) and access to human capital through their scientist-founders.

Lastly, this study provides ample evidence for the interaction of insitutional links and resource endowments through entrepreneurship and organization building. We provide some insight into how institutional linkages provide resource endowments to the employment system of the spinoff through the organization building of founders. This provides strong evidence for considering the role of academic entrepreneurs in the technology transfer literature (Hindle \& Yencken, 2004). The established links, including where to locate, not only imbues the spinoff with significant resources, but also influences the organization building efforts of founders and the founding team. BetaTech and GammaTech were embedded within their institutional origins and enjoyed advantages from it including the knowledge resources available to them. Such proximity has constraints, as well. AlphaTech, in order to maintain and create a venture outside the influence and confines of its institutional origins, and raise venture finance, largely severed formal institutional links. This reflects how institutional links may enhance our understanding of entrepreneurial agency in academic settings.

\section{REFERENCES AVAILABLE FROM THE AUTHORS}

Table 1. Inter-Institutional Linkages and Resource Endowments of Spin-offs

\begin{tabular}{|c|c|l|c|c|c|}
\hline Spinoff & $\begin{array}{c}\text { Inter- } \\
\text { institutional } \\
\text { Linkages }\end{array}$ & $\begin{array}{l}\text { Founder } \\
\text { Background }\end{array}$ & $\begin{array}{c}\text { Operational } \\
\text { Location }\end{array}$ & $\begin{array}{c}\text { Funding } \\
\text { Source }\end{array}$ & $\begin{array}{c}\text { Knowledge } \\
\text { Resources }\end{array}$ \\
\hline AlphaTech & Independent & $\begin{array}{l}\text { Alpha: } \\
\text { Former Professor } \\
\text { Prior commercial } \\
\text { experience }\end{array}$ & $\begin{array}{l}\text { Outside the } \\
\text { university }\end{array}$ & IPO & Separate \\
\hline BetaTech & Symbiotic & $\begin{array}{l}\text { Beta1: } \\
\text { Business-founder } \\
\text { CEO of TTO } \\
\text { Beta2: } \\
\text { Professor at Uni- } \\
\text { affiliated institute }\end{array}$ & $\begin{array}{c}\text { Within } \\
\text { university } \\
\text { precinct }\end{array}$ & $\begin{array}{c}\text { VC and } \\
\text { Uni }\end{array}$ & $\begin{array}{c}\text { Fluid } \\
\text { Buffered }\end{array}$ \\
\hline GammaTech & Embedded & $\begin{array}{l}\text { Gamma: } \\
\text { University } \\
\text { Professor } \\
\text { Prior Founding } \\
\text { Experience }\end{array}$ & $\begin{array}{c}\text { Co-location } \\
\text { with } \\
\text { university }\end{array}$ & $\begin{array}{l}\text { Founder } \\
\text { and Uni }\end{array}$ & Nested \\
\hline
\end{tabular}


Copyright of Academy of Management Proceedings is the property of Academy of Management and its content may not be copied or emailed to multiple sites or posted to a listserv without the copyright holder's express written permission. However, users may print, download, or email articles for individual use. 
Copyright of Academy of Management Proceedings is the property of Academy of Management and its content may not be copied or emailed to multiple sites or posted to a listserv without the copyright holder's express written permission. However, users may print, download, or email articles for individual use. 
Copyright of Academy of Management Annual Meeting Proceedings is the property of Academy of Management and its content may not be copied or emailed to multiple sites or posted to a listserv without the copyright holder's express written permission. However, users may print, download, or email articles for individual use. 